\title{
The Intestinal Brush Border Membrane in Diabetes
}

\author{
STUDIES OF SUCRASE-ISOMALTASE METABOLISM IN RATS WITH
} STREPTOZOTOCIN DIABETES

\author{
Ward A. Olsen and Helen Korsmo \\ From the Gastroenterology Research Laboratory, William S. Middleton Memorial Veterans \\ Administration Hospital and the Department of Medicine, Center for Health Sciences, \\ University of Wisconsin, Madison, Wisconsin 53706
}

\begin{abstract}
A B S T R A C T Diabetes stimulates the functional activity of the intestinal brush border membrane with enhancement of both hydrolytic enzyme activity and membrane transport systems. To determine the mechanism of this effect, we studied the effects of streptozotocin diabetes on the metabolism of one membrane protein, sucrase-isomaltase, which increases its activity in diabetes. The protein was purified and an antiserum prepared. Sucrase-isomaltase from control and diabetic rats was immunologically identical as shown by Ouchterlony double-diffusion analysis of papainsolubilized mucosal proteins. The increase in sucrase enzyme activity in diabetic animals $(31.0 \pm 1.4 \mathrm{U}$ SEM 5 days after streptozotocin vs. $13.1 \pm 1.0$ in controls) was the consequence of increased enzyme protein and not an alteration in catalytic efficiency as demonstrated by quantitative immunoprecipitin reactions.

To account for increased sucrase-isomaltase protein in diabetes we studied papain-solubilized mucosal proteins labeled by injection of $\left[{ }^{14} \mathrm{C}\right]$ carbonate and $\left[{ }^{14} \mathrm{C}\right]$ leucine and analyzed incorporation into sucraseisomaltase protein (anti-serum precipitable) and total protein (trichloroacetic acid precipitable). We found that diabetes did not affect the decay of labeled total protein, but prolonged the decay of labeled sucraseisomaltase. $t_{1}$ of sucrase-isomaltase was $4.4 \mathrm{~h}$ in control animals after $\left[{ }^{14} \mathrm{C}\right]$ carbonate injection and 8.8 and $10.2 \mathrm{~h}$, respectively, 2 and 5 days after induction of streptozotocin diabetes. We obtained similar results in experiments with $\left[{ }^{14} \mathrm{C}\right]$ leucine with diabetes increasing $\mathrm{t}_{\mathrm{t}}$ from 6 to $13.6 \mathrm{~h}$. Diabetes did not appear to increase the rate of addition of sucrase-isomaltase to the brush border membrane, since it did not affect the 10 - and 60-min incorporations of isotope into sucrase-
\end{abstract}

Received for publication 11 January 1977 and in revised form 16 March 1977. isomaltase protein relative to incorporation into total protein and did not alter rate constants for synthesis calculated from the $t_{\frac{1}{2}}$ and the change in enzyme mass over time.

Thus, enhanced sucrase activity in the diabetic animal is the consequence of an increase in sucraseisomaltase protein which develops because of a decrease in its rate of degradation.

\section{INTRODUCTION}

Insulin deficiency stimulates the functional activity of the brush border membrane of the intestinal absorptive cell. For example, experimental diabetes has been reported to increase the enzymatic activity of many brush border hydrolases including the disaccharidases (1-4) and to stimulate a number of transport systems believed to reside in this membrane (5-10). Diabetes mellitus in man has also been associated with increased intestinal disaccharidase activity $(11,12)$ and enhanced glucose absorption (13), although negative studies in man have also been reported $(14,15)$ perhaps because of differing severity of the disease and effects of treatment. We have examined the effects of experimental diabetes on the metabolism of a representative brush border membrane enzyme, sucrase, to obtain some insight into the mechanism of the increased function of this membrane in diabetes. Our results indicate that increased enzyme activity is the consequence of an increase in sucrase-isomaltase protein which develops because of a decrease in its rate of degradation.

\section{METHODS}

Male Sprague-Dawley rats weighing approximately $160 \mathrm{~g}$ were used. Diabetes was produced by an intravenous injection of streptozotocin (The Upjohn Co., Kalamazoo, Mich.), 


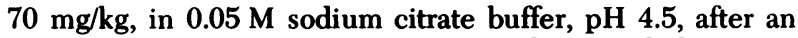
overnight fast. The animals were housed in metabolic cages, and 24-h urine collections were tested for glucose (Clinistix, Ames Co., Div. of Miles Lab., Inc., Elkhart, Ind.). Only those rats with heavy glucosuria $(500 \mathrm{mg} / 100 \mathrm{ml}$ or more) which corresponds to a blood glucose at the time of sacrifice of $300-500 \mathrm{mg} / 100 \mathrm{ml}$ (7) were used for study. Control animals were similarly fasted for $24 \mathrm{~h}$, but not injected. After fasting, all rats were allowed free access to standard laboratory food and water. 2 or 5 days after injection of streptozotocin, diabetic and control rats were given either $20 \mu \mathrm{Ci}$ of $\left[{ }^{14} \mathrm{C}\right]$ leucine $\left(\mathrm{L}-\left[1-{ }^{14} \mathrm{C}\right]\right.$ leucine, sp act $>50 \mathrm{mCi} /$ mmol, New England Nuclear, Boston, Mass.) or $300 \mu \mathrm{Ci}$ $\left[{ }^{14} \mathrm{C}\right]$ sodium carbonate (sp act $2-10 \mathrm{mCi} / \mathrm{mmol}$, New England Nuclear) by tail vein between 7 and 8 a.m. after an overnight fast. Thereafter they were allowed free access to water but food was withheld. Animals were sacrificed at intervals to $24 \mathrm{~h}$. The small intestine from the ligament of Treitz to the cecum was removed, flushed with ice-cold saline, everted, rinsed with saline, and scraped with a glass slide over ice to remove the mucosa. Mucosa from each rat was homogenized in $0.1 \mathrm{M}$ potassium phosphate buffer, $\mathrm{pH} 7.4$ $(5 \mathrm{ml} / \mathrm{g}$ of mucosa) over ice for 10 and then $15 \mathrm{~s}$ with a Polytron homogenizer at setting no. 4 (Brinkmann Instruments, Inc., Westbury, N. Y.). After addition of $0.2 \mathrm{mg} / \mathrm{ml}$ papain and $0.2 \mathrm{mg} / \mathrm{ml}$ cysteine (Sigma Chemical Co., St. Louis, Mo.) the homogenates were incubated at $37^{\circ} \mathrm{C}$ for $60 \mathrm{~min}$ and then centrifuged for $60 \mathrm{~min}$ at $105,000 \mathrm{~g}$ at $4^{\circ} \mathrm{C}$. Supernatant fractions were then dialyzed against $0.1 \mathrm{M}$ potassium phosphate buffer, pH 7.4, overnight in the cold. Dialyzed supernatant fractions will be subsequently referred to as papain supernates.

The technique of Siekevitz (16) was used to isolate total protein in papain supernatant fractions. In duplicate runs, protein was precipitated with trichloroacetic acid after which nucleic acid was removed with hot trichloroacetic acid and lipid with alcohol-ether-chloroform and ether. The final air-dried residue was dissolved in $300 \mu$ l of $0.3 \mathrm{~N}$ sodium hydroxide for determination of protein and radioactivity.

Sucrase-isomaltase protein was determined using the following technique. Sufficient antiserum to precipitate all enzyme activity was added to three aliquots of each papain supernate in centrifuge tubes. In practice, $0.02 \mathrm{ml}$ of antiserum was added to aliquots containing $0.47 \mathrm{U}$ of sucrase activity made up to identical volumes with isotonic saline. The tubes were then held at $4^{\circ} \mathrm{C}$ for 2 days and centrifuged at $1,000 \mathrm{~g}$ for $15 \mathrm{~min}$ at $4^{\circ} \mathrm{C}$. The pellet was washed three times with isotonic saline and dissolved in $100 \mu \mathrm{l}$ of $0.3 \mathrm{~N}$ sodium hydroxide. Solubilized pellets from two tubes were assayed separately for radioactivity, and the pellet from the third tube was used to measure protein (26). To ensure that all enzyme had been precipitated, the supernate from one of the three tubes was assayed for sucrase activity, but in no case was enzyme activity found. To correct for nonspecific precipitation (17), the supernate was removed from one tube, and to the supernate was added nonradioactive papain supernate containing $0.47 \mathrm{U}$ of sucrase. Immunoprecipitation was again performed and the precipitate counted. This precipitate contained no labeled enzyme but did contain whatever radioactivity was trapped in the antigen-antibody complex. Disintegrations per minute in this pellet was subtracted from mean disintegrations per minute of the two initial precipitates to obtain the disintegrations per minute of sucrase-isomaltase. Addition of control, nonimmune serum to papain supernates resulted in no precipitation.

Total radioactivity of papain-supernatant protein and sucrase-isomaltase protein was plotted against time on semilogarithmic paper for calculation of half-lives. Differences in the slopes of the lines were assessed by the method given by Goldstein (18).

Purification of sucrase-isomaltase. 30 Sprague-Dawley rats were sacrificed, and the intestinal mucosa was removed by scraping. Brush borders were prepared by the method of Forstner et al. (19) and added to sufficient $0.05 \mathrm{M}$ potassium phosphate buffer, pH 7.2 , to yield a protein concentration of $4 \mathrm{mg} / \mathrm{ml}$. After sonication with a Bronwill probe sonicator (VWR Scientific Div., UNIVAR, San Francisco, Calif.) for $30 \mathrm{~s}$ at the lowest setting (20), $0.2 \mathrm{mg} / \mathrm{ml}$ papain and $2.0 \mathrm{mg} / \mathrm{ml}$ cysteine were added, and the mixture was incubated at $37^{\circ} \mathrm{C}$ for $60 \mathrm{~min}$. The mixture was centrifuged at $105,000 \mathrm{~g}$ for $60 \mathrm{~min}$ at $4^{\circ} \mathrm{C}$, and the supernate was treated as described by Kolinska and Kraml (21). Briefly, the supernate was precipitated with ethanol at $-15^{\circ} \mathrm{C}$, and the precipitate was dissolved in $0.01 \mathrm{M}$ potassium phosphate buffer, $\mathrm{pH} 7.4$. After centrifugation at $105,000 \mathrm{~g}$ for $60 \mathrm{~min}$ at $4^{\circ} \mathrm{C}$, the supernate was applied to a $5 \times 100-\mathrm{cm}$ column packed with Sephadex G-200 (Pharmacia Fine Chemicals, Div. of Pharmacia, Inc., Piscataway, N. J.) and eluted with potassium phosphate buffer. The sucrase-containing fractions were combined and applied to a DEAE-cellulose column equilibrated with $0.01 \mathrm{M}$ potassium phosphate buffer, pH 7.4. After a wash with $500 \mathrm{ml}$ of this buffer, a shallow chloride gradient was applied to release sucraseisomaltase. The protein was concentrated by filtration using an Amicon PM 10 filter (Amicon Corp., Lexington, Mass.) to a protein concentration of $0.81 \mathrm{mg} / \mathrm{ml}$ and stored at $-20^{\circ} \mathrm{C}$ until use.

To assess homogeneity of purified sucrase-isomaltase, 12 $\mu \mathrm{g}$ of protein was subjected to acrylamide gel electrophoresis (22) in 7.5\% acrylamide in two pH systems: an anionic gel system at $\mathrm{pH} 9.56$ with a $3.3 \%$ spacer gel and a cationic gel system at $\mathrm{pH} 4.3$ with a $2.5 \%$ spacer gel. $5 \times 120-\mathrm{mm}$ tubes were used with $2-3 \mathrm{~mA}$ per tube until a bromphenol blue tracking dye migrated within 3-5 $\mathrm{mm}$ from the end. Gels were stained with Coomassie Blue (23).

Preparation of antiserum. $0.5 \mathrm{mg}$ of purified sucraseisomaltase protein was mixed with Freund's complete adjuvant in a $1: 1$ volume ratio and injected subcutaneously into a rabbit. The injection was repeated 28 days later; 1 wk thereafter the rabbit was bled from an ear vein. Serum was stored at $-70^{\circ} \mathrm{C}$ until use. Control antiserum was obtained from rabbits which received only Freund's adjuvant.

Double diffusion in agar gel was carried out as described by Ouchterlony (24) and quantitative precipitin reactions as described by Kabat and Mayer (25).

Chemical, enzymatic, and radioactivity determinations. Protein was determined by the method of Lowry et al. (26) and sucrase activity by the method of Dahlqvist (27). Radioactivity was measured by mixing up to $0.2-\mathrm{ml}$ aliquots with $15 \mathrm{ml}$ of toluene: alcohol: Liquifluor (New England Nuclear), 1,000:375:42, and by counting in a liquid scintillation spectrometer (Isocap/300, G. D. Searle and Co., Chicago, Ill.) with an efficiency for ${ }^{14} \mathrm{C}$ of $70 \%$. Disintegrations per minute were determined by an external standard-channels ratio technique.

\section{RESULTS}

Preparation of antibody. Purified sucrase-isomaltase was applied to acrylamide gels and subjected to electrophoresis at two different $\mathrm{pH}$ 's. The protein appeared homogeneous by this criterion as shown by representative gels in Fig. 1. Rabbit antiserum after 


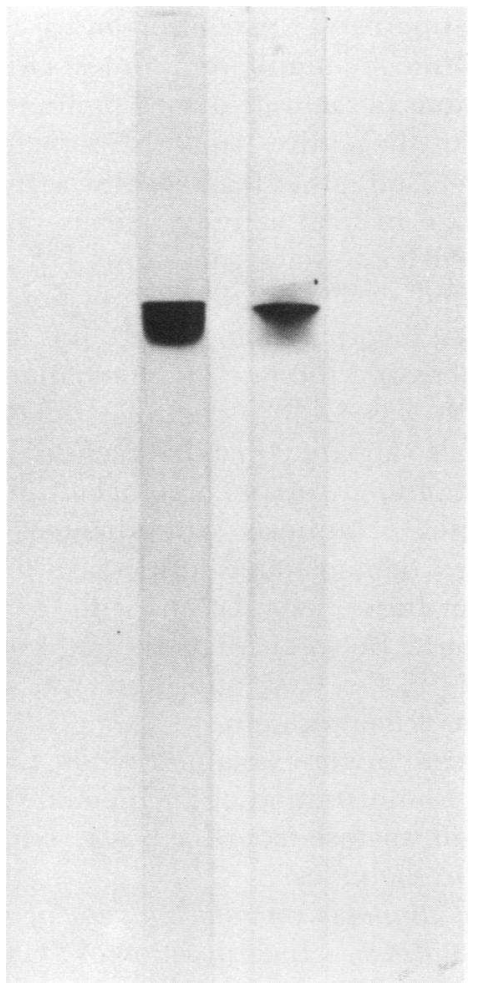

FIGURE 1 Acrylamide gel electrophoresis of purified sucraseisomaltase. $12 \mu \mathrm{g}$ of protein was applied to each gel. The gel on the left was a pH 4.3 system and the gel on the right a pH 9.56 system.

immunization with the protein was used in Ouchterlony gel double-diffusion studies. Fig. 2 demonstrates such an analysis with antiserum applied to the center well $\mathrm{D}$, homogeneous sucrase-isomaltase to well $\mathrm{A}$, papain supernate from a control animal to well $C$, and papain supernate from a diabetic animal to well $B$. A single connecting precipitin band was found indicating the presence of a single antigenic protein in purified

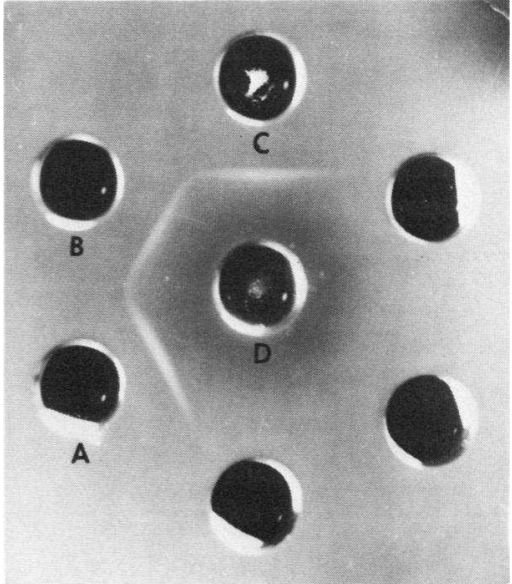

Figure 2 Ouchterlony double diffusion in agar gel. The center well, D, contained $100 \mu$ l of antiserum, well A $0.75 \mathrm{U}$ of sucrase in purified sucrase-isomaltase, well B $0.75 \mathrm{U}$ of sucrase in papain supernate from a diabetic animal, and well C $0.75 \mathrm{U}$ of sucrase in papain supernate from a control animal.

sucrase-isomaltase and the presence of a single antibody in the antiserum reactive with papain supernates. This study also suggests the immunological identity of sucrase-isomaltase whether obtained from control or diabetic intestine.

Content of sucrase-isomaltase protein. Diabetes resulted in an increase in intestinal mucosal sucrase activity. Table I demonstrates that both total activity and activity per gram protein were increased in mucosal homogenates and papain supernates 5 days after injection of streptozotocin. The results of quantitative precipitin reactions of sucrase-isomaltase from control and diabetic papain supernates are shown in Fig. 3. The quantity of protein precipitated when sucrase from control and diabetic papain supernates were added was virtually the same when based on the amount of enzyme activity. This demonstrates that the differences in enzyme activity between control and diabetic papain

TABLE I

Effects of 5 Days of Diabetes on Sucrase Activity

\begin{tabular}{|c|c|c|c|c|c|c|}
\hline & \multicolumn{3}{|c|}{ Mucosal homogenates } & \multicolumn{3}{|c|}{ Papain supernates } \\
\hline & $\begin{array}{l}\text { Total sucrase } \\
\text { activity }\end{array}$ & Total protein & $\begin{array}{l}\text { Specific } \\
\text { activity }\end{array}$ & $\begin{array}{l}\text { Total sucrase } \\
\text { activity }\end{array}$ & Total protein & $\begin{array}{l}\text { Specific } \\
\text { activity }\end{array}$ \\
\hline & $\mu \mathrm{mol} / \mathrm{min}$ & g & & $\mu \mathrm{mol} / \mathrm{min}$ & $g$ & \\
\hline Controls (18) & $10.0 \pm 1.6$ & $0.296 \pm 0.018$ & $34 \pm 3$ & $13.1 \pm 1.0$ & $0.0750 \pm 0.004$ & $180 \pm 10$ \\
\hline Diabetics (17) & $27.1 \pm 1.9$ & $0.314 \pm 0.017$ & $91 \pm 8$ & $31.0 \pm 1.4$ & $0.0795 \pm 0.005$ & $390 \pm 20$ \\
\hline \multicolumn{7}{|l|}{ Significance } \\
\hline of difference* & $P<\dot{0.001}$ & NS & $P<0.001$ & $P<0.001$ & NS & $P<0.001$ \\
\hline
\end{tabular}

Mean \pm SEM are given. Numbers of animals are given in parentheses.

* Student's $t$ test. 


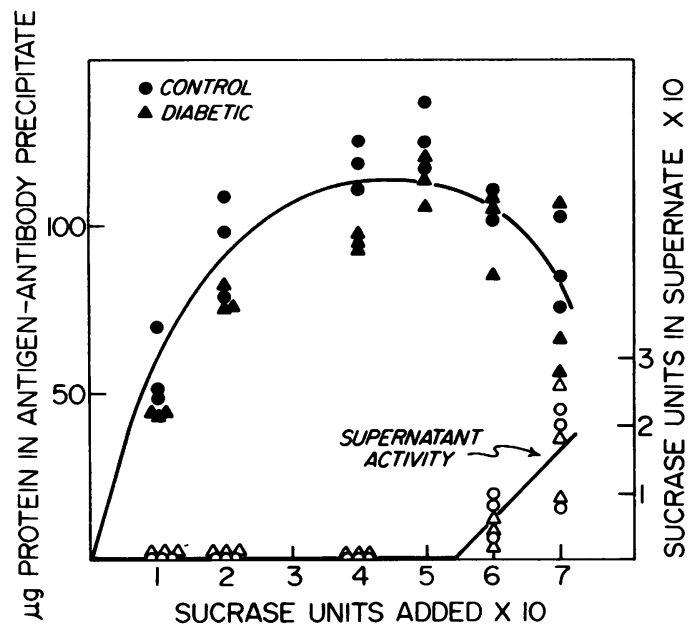

FIGURE 3 Quantitative immunoprecipitin reactions of sucrase-isomaltase from control and diabetic rats. To $20 \mu \mathrm{l}$ of antiserum were added papain supernates from individual control and diabetic animals containing the enzyme activity indicated. Precipitation was carried out as described in Methods. The closed symbols indicate the protein content of antigen-antibody precipitates and the open symbols the enzyme activity in the supernates after removal of precipitates.

supernates result from differences in amounts of immunologically reactive protein. This point can be more clearly made by a consideration of the quantity of antigen-antibody complex precipitated from the entire papain supernate. Control supernates yielded $6.6 \pm 0.6$ mg SEM of precipitate protein and diabetic supernates $14.2 \pm 0.7, P<0.001$ (Student's $t$ test).

It should also be noted that Fig. 3 illustrates the coincidence of maximum protein precipitation with the end point of titration of enzyme activity against antiserum indicating high specificity of the antiserum for sucrase-isomaltase.

Studies of degradation of sucrase-isomaltase. To study the effect of diabetes on degradation of sucraseisomaltase, we administered $\left[{ }^{14} \mathrm{C}\right]$ sodium carbonate to label intestinal proteins. Table II shows the radio- activity of total protein and sucrase-isomaltase protein in papain supernates in control and 5-day diabetic animals sacrificed at different times after injection. Disintegrations per minute of total protein and sucraseisomaltase in the entire papain supernate from each animal were used rather than specific activity because only a change in total activity reflects protein breakdown in nonsteady-state conditions [28]. When this data is plotted as disintegrations per minute vs. time after maximal incorporation (Fig. 4), it is apparent that diabetes decreased the rate of degradation of sucraseisomaltase. $t_{1}$ was $4.4 \mathrm{~h}$ in controls and $10.2 \mathrm{~h}$ in diabetics. It is also apparent that diabetes did not diminish degradation of total papain supernatant protein.

Our studies of animals with diabetes of a 2-day duration also demonstrated a decrease in the rate of sucrase-isomaltase degradation with a $t_{\frac{1}{2}}$ of $8.8 \mathrm{~h}$. The difference between diabetic and control slopes was significant, $P<0.02$, and there was no effect on degradation of total protein.

Similar results were obtained when proteins were labeled by administration of $\left[{ }^{14} \mathrm{C}\right]$ leucine as shown in Fig. $5 ; t_{1}$ for sucrase-isomaltase was $6 \mathrm{~h}$ in controls and $13.6 \mathrm{~h}$ in diabetics.

Effects of diabetes on relative rate of synthesis of sucrase-isomaltase. Incorporation of ${ }^{14} \mathrm{C}$ into sucraseisomaltase 10 and $60 \mathrm{~min}$ after injection of $\left[{ }^{14} \mathrm{C}\right]$ leucine was studied to obtain some information on the effects of diabetes on synthetic rates of the enzyme. Results were expressed relative to incorporation into total protein to correct for differences in pool sizes. Table III demonstrates that diabetes did not affect incorporation of isotope into sucrase-isomaltase relative to total protein at either 10 or $60 \mathrm{~min}$.

Effects of diabetes on calculated synthetic rate constants. We also calculated rate constants for synthesis in control and diabetic animals using formulas described by Berlin and Schimke (29). In controls, assuming a steady state where synthesis is equal to degradation, $S=P \cdot K$, where $S=$ the rate constant for synthesis, $P=$ initial enzyme mass per animal, and

TABLE II

Radioactivity of Papain Supernatant Proteins after $\left[{ }^{[4} \mathrm{C}\right]$ Sodium Carbonate

\begin{tabular}{|c|c|c|c|c|}
\hline \multirow{2}{*}{$\begin{array}{l}\text { Hours after } \\
\text { injection }\end{array}$} & \multicolumn{2}{|c|}{ Controls } & \multicolumn{2}{|c|}{ Diabetics } \\
\hline & Sucrase-isomaltase & Total protein & Sucrase-isomaltase & Total protein \\
\hline 2 & $2,200 \pm 100(3)$ & $55,800 \pm 3,900(3)$ & $3,800 \pm 1,000(3)$ & $92,000 \pm 31,900(3)$ \\
\hline 4 & $2,100 \pm 100(3)$ & $48,200 \pm 5,700(3)$ & $3,200 \pm 1,000(3)$ & $63,700 \pm 12,000(3)$ \\
\hline 6 & $1,900 \pm 400(2)$ & $83,000 \pm 9,200(2)$ & $5,400 \pm 800$ & $83,600 \pm 17,000(3)$ \\
\hline 8 & $2,900 \pm 300(2)$ & $57,600 \pm 5,900(2)$ & $4,300 \pm 70$ & $82,700 \pm 27,200(2)$ \\
\hline 12 & $2,200 \pm 800(3)$ & $81,800 \pm 8,200(3)$ & $4,800 \pm 500$ & $96,300 \pm 12,300(3)$ \\
\hline 24 & $300 \pm 10$ & $72,500 \pm 9,300(3)$ & $1,900 \pm 300$ & $63,800 \pm 15,300(3)$ \\
\hline
\end{tabular}

$300 \mu \mathrm{Ci}$ of $\left[{ }^{14} \mathrm{C}\right]$ sodium carbonate was injected intravenously as described in Methods. Total disintegrations per minute of papain supernatant total protein and sucrase-isomaltase protein were measured in each animal. Results are given as mean $\pm \mathrm{SEM}$. Number of animals are given in parentheses. 


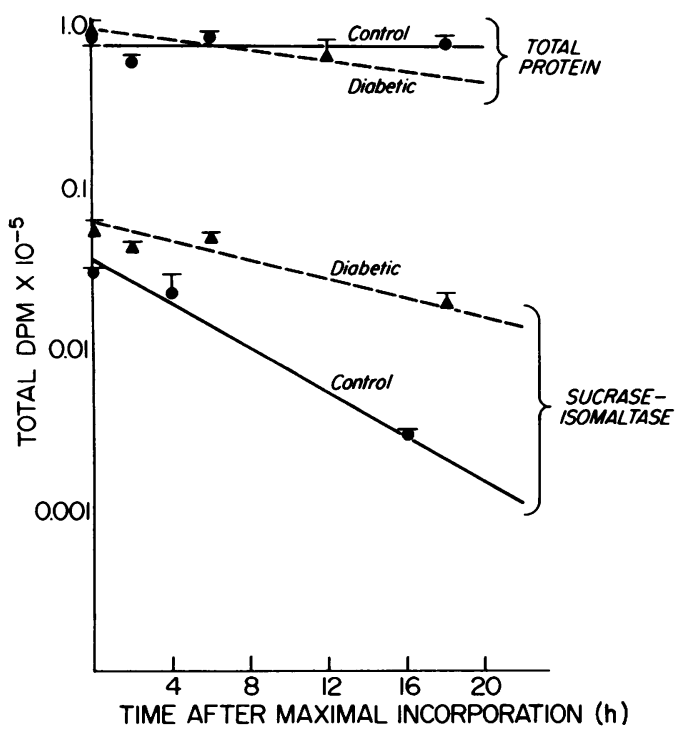

FIGURE 4 Effects of diabetes of a 5-day duration on degradation of sucrase-isomaltase after labeling with $\left[{ }^{14} \mathrm{C}\right]$ sodium carbonate. The data of Table II were plotted as total disintegrations per minute of sucrase-isomaltase protein and total papain supernatant proteins vs. time after maximal incorporation. Means \pm SEM are shown. Regression lines were calculated by the least squares method using individual values. The difference between diabetic and control slopes for sucrase-isomaltase was significant, $P<0.001$. $t_{1}$ of sucrase-isomaltase was $4.4 \mathrm{~h}$ in controls and $10.2 \mathrm{~h}$ in diabetics.

$K=$ rate constant for degradation. $P$ was calculated from the mean sucrase activity in papain supernates and the specific activity of the purified protein and $K$ from the relationship $t_{i}=(\ln 2) / K$. In diabetics, assuming a new rate constant for degradation, $K^{\prime}$, occurs instantaneously (which is not unreasonable since there was no statistical difference between $t_{\frac{1}{2}}$ in 2-day diabetics and $t_{\frac{1}{2}}$ in 5-day diabetics),

$$
S=\frac{K^{\prime}\left(P-P_{o} \cdot e^{-K^{\prime} \cdot T}\right)}{1-e^{-K^{\prime} T}},
$$

where $K^{\prime}$, the rate constant in diabetics, is derived from $t_{1}=(\ln 2) / K^{\prime}, P_{o}=$ the original enzyme mass per rat (i.e., mean mass in controls), $P=$ mean enzyme mass per rat after 5 days of diabetes, and $\mathrm{T}=$ time $(120 \mathrm{~h})$. Calculated rate constants for synthesis for controls and diabetics were the same $(0.113 \mathrm{mg} / \mathrm{h}$ in controls and 0.110 in diabetics).

\section{DISCUSSION}

Experimental diabetes is associated with a variety of functional changes in the intestinal brush border membrane. There is an increase in the total and specific enzymatic activity of several membrane-bound hydrolases including sucrase, maltase, lactase, trehalase, leucylnaphthylamidase, and alkaline phosphatase (1-4). In addition, enhancement of active

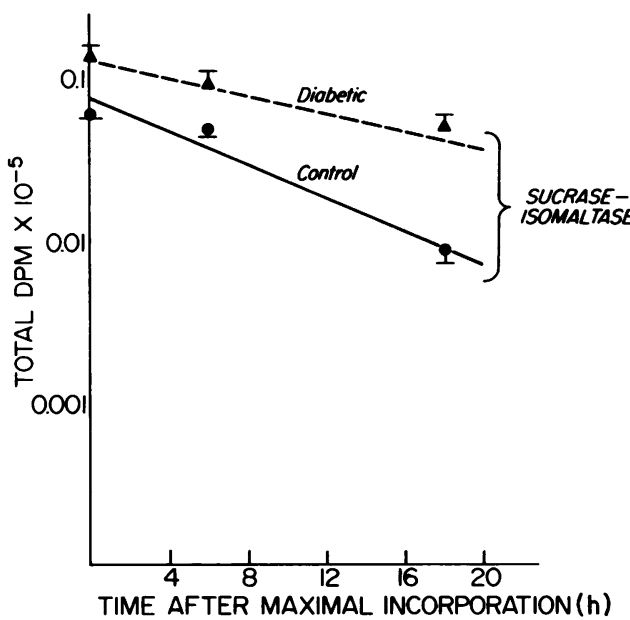

FIGURE 5 Effects of diabetes of a 5-day duration on degradation of sucrase-isomaltase after labeling with $\left[{ }^{14} \mathrm{C}\right]$ leucine. Methods were the same as given for Fig. 4. Mean \pm SEM from three animals are given for each time point. The difference between diabetic and control slopes was significant, $P<0.02$. $t_{1}$ for sucrase-isomaltase was $6.0 \mathrm{~h}$ in controls and $13.6 \mathrm{~h}$ in diabetics.

transport mechanisms for monosaccharides (5-7), amino acids (7), sodium (8), and bile acids (9) has been reported; that this enhancement is also the result of a membrane effect is suggested by the recent observation of increased glucose transport by isolated brush border membrane vesicles prepared from diabetic animals (10). We sought to investigate the mechanism of these changes by studying the metabolism in vivo of one representative protein, sucraseisomaltase.

Since enhancement of activity of an enzyme may be the consequence of either an increase in the amount of enzyme protein present or an increase in the

TABLE III

Effect of Diabetes on Relative Rates of Synthesis of Sucrase-Isomaltase

\begin{tabular}{lcc}
\hline & \multicolumn{2}{c}{ Incorporation time } \\
\cline { 2 - 3 } & $10 \mathrm{~min}$ & $60 \mathrm{~min}$ \\
\hline Controls & $0.215 \pm 0.115(3)$ & $0.676 \pm 0.088(3)$ \\
$\begin{array}{l}\text { Diabetics } \\
\text { Significance of } \\
\text { difference* }\end{array}$ & $0.295 \pm 0.051(3)$ & $0.784 \pm 0.058(3)$ \\
& $\mathrm{NS}$ & $\mathrm{NS}$ \\
\hline
\end{tabular}

$20 \mu \mathrm{Ci}$ of $\left[{ }^{14} \mathrm{C}\right]$ leucine was injected intravenously and the animals sacrificed 10 and 60 min later. Incorporation of ${ }^{14} \mathrm{C}$ into papain supernatant total protein and sucrase-isomaltase protein was determined as described in Methods. Disintegrations per minute of sucrase-isomaltase were divided by disintegrations per minute of total protẹin to determine relative rates of synthesis. Means \pm SEM are given. Numbers of animals are given in parentheses.

* Student's $t$ test. 
catalytic efficiency of the enzyme, e.g. the increased efficiency of alkaline phosphatase in HeLa 65 cells after cortisol (30), it was important first to determine that the increased sucrase activity in diabetic intestine was accompanied by an increase in sucraseisomaltase protein. Our quantitative precipitin studies, as shown in Fig. 3, demonstrate that similar amounts of sucrase-isomaltase protein from control and diabetic animals have similar enzymatic activities. Thus, the diabetic intestine contains more sucrase-isomaltase protein. The reason for this increase in enzyme protein might be an increase in the rate of synthesis of the protein, a decrease in rate of degradation, or both.

To study degradation of sucrase-isomaltase, we labeled proteins by intravenous injection of $\left[{ }^{14} \mathrm{C}\right]$ sodium carbonate. The rationale for both the route of administration and use of this isotope needs discussion. $\left[{ }^{14} \mathrm{C}\right]$ Sodium carbonate has been used extensively to label proteins, partly because it reduces the major problem in studies of protein degradation, reutilization of the labeled amino acid $(31)$. $\left[{ }^{14} \mathrm{C}\right]-$ Carbonate labels the cellular bicarbonate pool which exchanges with the carboxyl groups of glutamate and aspartate. Newly synthesized protein then becomes labeled with $\left[{ }^{14} \mathrm{C}\right]$ glutamate and $\left[{ }^{14} \mathrm{C}\right]$ aspartate. Since the bicarbonate pool turns over very rapidly, it is essentially unlabeled by the time significant protein degradation has occurred, and released glutamate and aspartate rapidly lose their label. Thus reutilization of labeled amino acid is minimized (32). This method may be the best technique, therefore, for studying degradation rates of proteins (33).

We gave considerable thought to the route of administration of isotope. Alpers has shown that intravenous injection of precursor amino acid labels proteins from crypt cells more readily than proteins from villus cells and found the converse after intraluminal injection; this suggests that studies of metabolism of villus cell proteins, such as sucrase-isomaltase, might better be done with intraluminal injection of precursor (34). We decided upon intravenous administration, however, for two reasons. First, we wished to use the $\left[{ }^{14} \mathrm{C}\right]$ carbonate method where, presumably, most labeled amino acid would arrive via the vascular system anyway. Second, we wanted to use the entire jejunum and ileum, which could be labeled conveniently in $\left[{ }^{14} \mathrm{C}\right]$ leucine studies by intravenous injection, to provide enough papain supernate to allow studies of individual animals and to provide a more reproducible segment length.

Our studies confirm several previous observations concerning protein metabolism in normal intestine. After injection of isotope there was a lag of 6-8 h before maximal labeling of papain supernatant proteins and sucrase-isomaltase (Table II); a similar lag attributed to transfer of newly synthesized proteins to the brush border was found by James et al. (35) in studies of labeling of brush borders and purified disaccharidases after leucine injection. Our studies also confirm the rapid turnover of sucrase-isomaltase $\left(t_{\frac{1}{2}}\right.$ of $4.4 \mathrm{~h}$ with the carbonate method), much faster than cell turnover time. Das and Gray obtained at $t_{\frac{1}{2}}$ of $6 \mathrm{~h}$ of sucrase (36) and James and colleagues at $\mathrm{t}_{\frac{1}{2}}$ of purified disaccharidases of $14 \mathrm{~h}$ (35). Turnover of brush border proteins was slower than turnover of disaccharidases in these studies and turnover of mucosal proteins in general even slower. This heterogeneity of brush border protein turnover was recently studied by Alpers who demonstrated a more rapid turnover of large molecular weight proteins including the disaccharidases and a slower turnover of lower molecular weight proteins. The larger molecular weight proteins tended to be removable by papain digestion and thus perhaps superficially located on the membrane (20). It should be noted that the $t_{1}$ for sucrase-isomaltase of $4.4 \mathrm{~h}$ after $\left[{ }^{14} \mathrm{C}\right]$ carbonate injection in our studies is somewhat lower than that reported by Das and Gray and that found by us after administration of $\left[{ }^{14} \mathrm{C}\right]$ leucine; this difference suggests less reutilization with the carbonate technique and a more accurate assessment of degradation rate (32).

Diabetes resulted in a marked decrease in the rate of degradation of sucrase-isomaltase in studies using either carbonate or leucine. This was true even 2 days after administration of streptozotocin suggesting that decreased turnover of sucrase-isomaltase is an early event in the diabetic animal. Could decreased decay of labeled sucrase-isomaltase in diabetes be artifactual and not a reflection of true degradation of the protein? The major problems with pulse-labeling methods of determining protein degradation have been: $(a)$ reutilization of the isotope and $(b)$ impurity of the isolated sample with radioactivity measured in a minor protein contaminent rather than in the protein of interest (31). We found that decay in the protein was prolonged, not only in studies using $\left[{ }^{14} \mathrm{C}\right]$ leucine as the precursor, but also in our $\left[{ }^{14} \mathrm{C}\right]$ carbonate studies where utilization is minimized. This makes it very unlikely that our results were the consequence of increased reutilization in the diabetic animal. The results of our agar double-diffusion and immunoprecipitin studies make it also very unlikely that we were measuring the radioactivity of a contaminent. Thus, we believe that decreased degradation of the enzyme in diabetes is a real phenomenon.

The possibility that our findings were the consequence of a decrease in absorptive cell turnover should be considered, especially since decreased cell turnover has been reported in two situations which have some similarity to experimental diabetes: partial starvation and repeated glucagon administration (37). Intestinal epithelial cell turnover in diabetes, however, has been reported to be normal or increased, but not decreased (38). More importantly, we found 
an effect on turnover of a single protein in papain supernatant fractions, but not on turnover of proteins in general. If the effect were primarily on cell turnover, degradation of total protein would be expected to be prolonged. Thus, it is very unlikely that prolonged degradation of sucrase-isomaltase is secondary to a primary effect on cell turnover.

We considered the possibility that diabetes also increased the rate of synthesis of sucrase-isomaltase. Alpers and Kinzie have summarized the difficulties of determining the true synthetic rates of intestinal proteins (33). Among these problems are the heterogeneous cell population of the intestine, the difficulty of labeling all villus cells, the likelihood that experimental manipulations, such as induction of diabetes, would change the amino acid pool size, and the lag time before maximal labeling of brush border proteins. We therefore attempted to measure a relative synthetic rate of sucrase-isomaltase, relating 10 - and 60 -min incorporations into that protein to incorporation into total papain supernatant proteins. As shown in Table III, diabetes did not appear to affect relative synthesis of sucrase-isomaltase. It should be stressed that this relative synthetic rate probably bears little relation to the true synthetic rate of the protein, but the studies do suggest that addition of this protein to the brush border membrane does not occur faster than addition of other papain-removable proteins in diabetes. In addition, diabetes did not affect the synthetic rate constant for sucrase as calculated from enzyme mass and $t_{1}$. Thus, diabetes does not appear to affect the rate of incorporation of sucrase-isomaltase into the brush border membrane.

The finding of an apparently normal synthetic rate with a decreased degradative rate suggests that enzyme activity will progressively increase with time. However, at some point it is likely that the synthetic rate will fall, otherwise, sucrase-isomaltase would continue to increase indefinitely. The available data are consistent with this suggestion: sucrase activity progressively increases for at least the first 5 days of diabetes and appears to reach a new steady state sometime during the $2 \mathrm{nd} \mathrm{wk}(4)$, presumably because a fall in synthetic rate.

Since the effects of experimental diabetes on brush border membrane functional proteins differ so strikingly both from the reduction in general protein synthesis found in skeletal and cardiac muscle (39) and from the increased protein catabolism suggested in liver (40), the possibility should be considered that the intestinal effects are not the consequence of the diabetes, but of an additional effect of streptozotocin or of an alteration in food consumption in the streptozotocin-injected animals. This possibility seems unlikely. The intestinal effects are prevented or markedly diminished by insulin therapy $(3,4,7)$, suggesting that they are in fact the result of insulin deficiency. They also occur in segments of intestine completely excluded from luminal continuity (41), thus they cannot be the direct consequence of altered food consumption. Finally, they do not occur in control animals pair-fed with diabetics $(1,7)$. We cannot completely exclude the possibility, however, that a more subtle alteration in patterns of food consumption might be important, perhaps by changing blood levels of hormones.

We can only speculate on the cause of altered degradation of sucrase-isomaltase in diabetes. Although altered degradation rates have frequently been found responsible for changes in enzyme activity in other mammalian tissues (31), mechanisms of altered enzyme activity in the intestine have rarely been studied. Alpers and Tedesco, however, have recently reported that enhanced activity of several brush border enzymes in rats subjected to subtotal pancreatectomy is the consequence of decreased degradative rates (42), probably because of diminished intraluminal proteases. Thus alterations in degradation may turn out to be an important control mechanism for intestinal enzyme levels. Whether our findings in diabetes are the result of enhanced resistance to degradation or inhibition of the mechanism of degradation is unknown. Since sucrase-isomaltase contains a large quantity of carbohydrate (43), it is tempting to speculate that some alteration in the carbohydrate moieties of the protein might increase its resistance to degradation, especially since changes in carbohydrate composition of other glycoproteins have been reported in diabetes (44). Whatever the basis for decreased degradation of sucrase-isomaltase, it is likely that stimulation of general brush border function in diabetes occurs through a similar mechanism.

\section{ACKNOWLEDGMENTS}

We are grateful to Dr. Robert W. Swick for helpful discussion. Furthermore, we would like to acknowledge the donation of streptozotocin from the Upjohn Co., Kalamazoo, Mich.

This study was supported by grant AM 13927 from the National Institutes of Health and by Veterans Administration Research Funds.

\section{REFERENCES}

1. Olsen, W. A., and L. Rogers. 1971. Jejunal sucrase activity in diabetic rats. J. Lab. Clin. Med. 77: 838-842.

2. Younoszai, M. K., and H. P. Schedl. 1972. Effect of diabetes on intestinal disaccharidase activities. J. Lab. Clin. Med. 79: 579-586.

3. Caspary, W. F., A. M. Rhein, and W. Creutzfeldt. 1972. Increase of intestinal brush-border hydrolases in mucosa of streptozotocin-diabetic rats. Diabetologia. 8: 412-414.

4. Olsen, W. A., H. L. Agresti, and V. Lorenzsonn. 1974. Intestinal disaccharidases in diabetic rats. Proceedings 
of an International Conference on the Anatomy, Physiology, and Biochemistry of Intestinal Adaptation, Titisee, West Germany. R. H. Dowling, and E. O. Riecken, editors. Friedrick-Karl-Schattauer-Verlag, Stuttgart.

5. Pauls, F., and D. R. Drury. 1942. The rate of glucose absorption from the intestine of diabetic rats. Am. J. Physiol. 137: 242-245.

6. Crane, R. K. 1961. An effect of alloxan-diabetes on the active transport of sugars by rat small intestine, in vitro. Biochem. Biophys. Res. Commun. 4: 436-440.

7. Olsen, W. A., and I. H. Rosenberg. 1970. Intestinal transport of sugars and amino acids in diabetic rats. $J$. Clin. Invest. 49: 96-105.

8. Rosenberg, I. H., and R. Schultz. 1971. Enhanced sodium transport and oxygen consumption by alloxan diabetic intestine. Clin. Res. 19: 402. (Abstr.)

9. Caspary, W. F. 1973. Effect of insulin and experimental diabetes mellitus on the digestive-absorptive function of the small intestine. Digestion. 9: 248-263.

10. Hopfer, U. 1975. Diabetes mellitus: changes in the transport properties of isolated intestinal microvillous membranes. Proc. Natl. Acad. Sci. U. S. A. 72: 2027-2031.

11. Tandon, R. K., L. M. Srivastava, and S. C. Pandey. 1975. Increased disaccharidase activity in human diabetics. Am. J. Clin. Nutr. 28: 621-625.

12. Cerda, J. J., H. Preiser, and R. K. Crane. 1972. Brush border enzymes and malabsorption: elevated disaccharidases in chronic pancreatic insufficiency with diabetes mellitus. Gastroenterology. 62: 841. (Abstr.)

13. Vinnik, I. E., F. Kern, Jr., and K. E. Sussman. 1965. The effect of diabetes mellitus and insulin on glucose absorption by the small intestine in man. J. Lab. Clin. Med. 66: $131-136$.

14. Arvanitakis, C., and W. A. Olsen. 1974. Intestinal mucosal disaccharidases in chronic pancreatitis. Am. J. Dig. Dis. 19: 417-421.

15. Genel, M., D. London, P. G. Holtzapple, and S. Segal. 1971. Uptake of alpha-methylglucoside by normal and diabetic human jejunal mucosa. J. Lab. Clin. Med. 77: 743-750.

16. Siekevitz, P. 1952. Uptake of radioactive alanine in vitro into the proteins of rat liver fractions. J. Biol. Chem. 195: 549-565.

17. Schimke, R. T., E. W. Sweeney, and C. M. Berlin. 1965. The roles of synthesis and degradation in the control of rat liver tryptophan pyrrolase. J. Biol. Chem. 240: $322-331$.

18. Goldstein, A. 1964. Biostatistics. Macmillan, Inc., New York. 272 pp.

19. Forstner, G. G., S. M. Sabesin, and K. J. Isselbacher. 1968. Rat intestinal microvillus membranes. Purification and biochemical characterization. Biochem. J. 106: $381-390$.

20. Alpers, D. H. 1972. The relation of size to the relative rates of degradation of intestinal brush border proteins. J. Clin. Invest. 51: 2621-2630.

21. Kolínská, J., and J. Kraml. 1972. Separation and characterization of sucrase-isomaltase and of glucoamylase of rat intestine. Biochim. Biophys. Acta. 284: 235-247.

22. Ornstein, L. 1964. Disc electrophoresis. I. Background and theory. Ann. N. Y. Acad. Sci. 121: 321-349.

23. Fairbanks, G., T. L. Steck, and D. F. H. Wallach. 1971. Electrophoretic analysis of the major polypeptides of the human erythrocyte membrane. Biochemistry. 10: 2606-2617.

24. Ouchterlony, O. 1958. Diffusion-in-gel method for immunological analysis. Prog. Allergy. 5: 1-78.

25. Kabat, E. A., and M. M. Mayer. 1961. In Experimental
Immunochemistry. Charles C Thomas, Springfield, Ill. 2nd edition. 72-76.

26. Lowry, O. H., N. J. Rosebrough, A. L. Farr, and R. J. Randall. 1951. Protein measurement with the Folin phenol reagent. J. Biol. Chem. 193: 265-275.

27. Dahlqvist, A. 1968. Assay of intestinal disaccharidases. Anal. Biochem. 22: 99-107.

28. Koch, A. L. 1962. The evaluation of the rates of biological processes from tracer kinetic data. I. The influence of labile metabolic pools. J. Thor. Biol. 3: 283-303.

29. Berlin, C. M., and R. T. Schimke. 1965. Influence of turnover rates on the responses of enzymes to cortisone. Mol. Pharmacol. 1: 149-156.

30. Cox, R. P., N. A. Elson, S. H. Tu, and M. J. Griffin. 1971. Hormonal induction of alkaline phosphatase activity by an increase in catalytic efficiency of the enzyme. J. Mol. Biol. 58: 197-215.

31. Schimke, R. T. 1970. Regulation of protein degradation in mammalian tissues. In Mammalian Protein Metabolism. H. N. Munro, editor. Academic Press, Inc., New York. 4: 177-228.

32. Millward, D. J. 1970. Protein turnover in skeletal muscle. I. The measurement of rates of synthesis and catabolism of skeletal muscle protein using $\left[{ }^{14} \mathrm{C}\right] \mathrm{Na}_{2} \mathrm{CO}_{3}$ to label protein. Clin. Sci. (Oxf.). 39: 577-590.

33. Alpers, D. H., and J. L. Kinzie. 1973. Regulation of small intestinal protein metabolism. Gastroenterology. 64: 471-496.

34. Alpers, D. H. 1972. Protein synthesis in intestinal mucosa. The effect of route of administration of precursor amino acids. J. Clin. Invest. 51: 167-173.

35. James, W. P. T., D. H. Alpers, J. E. Gerber, and K. J. Isselbacher. 1971. The turnover of disaccharidases and brush border proteins in rat intestine. Biochim. Biophys. Acta. 230: 194-203.

36. Das, B. C., and G. M. Gray. 1970. Intestinal sucrase: in vivo synthesis and degradation. Clin. Res. 18: 378. (Abstr.)

37. Rudo, N. D., I. H. Rosenberg, and R. W. Wissler. 1976. The effect of partial starvation and glucagon treatment on intestinal villus morphology and cell migration. Proc. Soc. Exp. Biol. Med. 152: 277-280.

38. Hanson, W., D. Miller, H. Schedl, and J. Osborne. 1976. Proliferation and migration of mucosal cells in small intestine of the diabetic rat. Clin. Res. 24: 534. (Abstr.)

39. Pain, V. M., and P. J. Garlick. 1974. Effect of streptozotocin diabetes and insulin treatment on the rate of protein synthesis in tissues of the rat in vivo. J. Biol. Chem. 249: 4510-4514.

40. Amherdt, M., V. Harris, A. E. Renold, L. Orci, and R. H. Unger. 1974. Hepatic autophagy in uncontrolled experimental diabetes and its relationships to insulin and glucagon. J. Clin. Invest. 54: 188-193.

41. Olsen, W. A., and H. Korsmo. 1975. Enhancement of intestinal sucrase activity in experimental diabetes: the role of intraluminal factors. J. Lab. Clin. Med. 85: 832-837.

42. Alpers, D. H., and F. J. Tedesco. 1975. The possible role of pancreatic proteases in the turnover of intestinal brush border proteins. Biochim. Biophys. Acta. 401: 28-40.

43. Kelly, J. J., and D. H. Alpers. 1973. Blood group antigenicity of purified human intestinal disaccharidases. J. Biol. Chem. 248: 8216-8221.

44. Spiro, R. G. 1973. Biochemistry of the renal glomerular basement membrane and its alterations in diabetes mellitus. N. Engl. J. Med. 288: 1337-1342. 